EXTENDED REPORT

\title{
Tumour necrosis factor $\alpha$ blocking agents in refractory adult Still's disease: an observational study of 20 cases
}

\author{
B Fautrel, J Sibilia, X Mariette, B Combe, the Club Rhumatismes ef Inflammation
}

Ann Rheum Dis 2005;64:262-266. doi: 10.1136/ard.2004.024026

See end of article for authors' affiliations

Correspondence to: Dr B Fautrel, Department of Rheumatology, PitiéSalpêtrière Hospital, 83 bd de l'Hôpital, 75013 Paris, France; bruno.fautrel@psl. ap-hop-paris.fr

Accepted 1 June 2004

Background: Consensus is lacking on treatment for corticosteroid resistant adult onset Still's disease (ASD). Objective: To assess anti-TNF $\alpha$ efficacy and tolerance in refractory ASD.

Methods: All departments of rheumatology and internal medicine in France were contacted by mail to identify cases of refractory ASD for which anti-TNF $\alpha$ had been used. Medical information was collected using a standardised questionnaire.

Results: Of 20 patients with mean age 40.7 years (range 18-74) at treatment start and mean disease duration 8.5 years (range 2-21), the clinical expression of ASD was predominantly systemic in five patients and polyarticular in 15. Response to corticosteroids and methotrexate had been considered inadequate in all patients. Infliximab was used to treat 15 patients, and etanercept used for 10; five had received both drugs consecutively. Steroids were concurrently used in 18 patients and an immunosuppressant in 17. At a mean (SD) follow up of 13 (14) months, complete remission had occurred in five cases (of 25 treatment sequences): one receiving etanercept and four infliximab. Partial response was observed in 16 cases (seven etanercept and nine infliximab). Treatment failed in four cases (two with each anti-TNF $\alpha$ ). At the last visit, anti-TNF $\alpha$ therapy was discontinued in 17 cases, 11 times because of lack (or loss) of efficacy, four times because of a side effect, and twice for other reasons.

Conclusion: Anti-TNF $\alpha$ therapy may be helpful for some patients with refractory ASD. However, most patients achieve only partial remission. Additional information is thus needed to evaluate more precisely the risk-benefit ratio of this treatment.

A dult onset Still's disease (ASD) is a rare condition, prevalence of which is estimated to be 1.5 cases per 100000 to 1.5 cases per $1000000 .^{1-3}$ Its expression is very polymorphic and its progression highly variable..$^{4-8}$ Although some patients have a unique flare without any recurrence, most have recurrences, which progress to a chronic form of the disease. ${ }^{9}$ The literature distinguishes two main chronic forms: a systemic form with fever, asthenia, and other general symptoms, and an arthritic form with polyarthritis, which is sometimes erosive. ${ }^{4-7} 9-11$

Because of its low prevalence and its heterogeneous expression, randomised controlled trials are difficult to perform in ASD patients. Thus, all available evidence concerning effective therapies has emerged from open label studies. Aspirin and other non-steroidal anti-inflammatory drugs have been found to stabilise the disease in only $10-30 \%$ of patients. ${ }^{6}{ }^{11}$ In fact, corticosteroids are the preferred treatment, resulting in a clinical response in $76-95 \%$ of patients. ${ }^{410-13}$ However, dependence on or resistance to steroids is common, and other treatments are needed. By homology with rheumatoid arthritis, several disease modifying antirheumatic drugs (DMARDs), including gold salts, hydroxychloroquine, D-penicillamine, sulfasalazine, and cyclophosphamide, have been tested..$^{4-12} 14{ }^{15}$ More recently, two other treatments have been found to be effective in cases of steroid dependence or resistance: methotrexate ${ }^{16-19}$ and polyvalent intravenous immunoglobulin (IV Ig). ${ }^{20-22}$ As several immunological studies have previously shown that Th- 1 cytokines, specifically $\mathrm{TNF} \alpha$, are involved in ASD pathogenesis, anti-TNF $\alpha$ agents, which are highly efficient in rheumatoid arthritis and ankylosing spondylitis, ${ }^{23}{ }^{24}$ have been also evaluated in ASD. Apart from reports of a few isolated cases, only the results of three open label studies have been published. ${ }^{25-28}$ Two studies were retrospective and included five and six patients respectively, treated with either etanercept or infliximab. ${ }^{26}{ }^{27}$ The other study was a prospective open label trial of 12 patients with established ASD treated with etanercept. ${ }^{28}$ Thus, complete and partial remission might be achieved with anti-TNF $\alpha$ therapy in some subsets of patients.

The Club Rhumatismes and Inflammation, a section of the French Society of Rheumatology dedicated to the study of inflammatory rheumatisms, organised a survey in French hospitals to retrospectively evaluate the efficacy and tolerance of anti-TNF $\alpha$ in the treatment of ASD.

\section{MATERIALS AND METHODS}

Patient identification

This retrospective study was based on a national postal survey of the departments of rheumatology and internal medicine in all French hospitals; general or teaching. Departments that had treated patients with established ASD, according to Yamaguchi classification criteria, ${ }^{29}$ who were resistant to conventional DMARD therapy, for whom anti-TNF $\alpha$ therapy had been tested, were sent a standardised questionnaire asking about age and symptoms at ASD diagnosis, classification criteria, treatments tested before anti-TNF $\alpha$ therapy, and items related to the therapy.

\section{Anti-TNF $\alpha$ therapy}

At the time of the survey, only etanercept and infliximab were available in France. Patients receiving either drug were eligible, whatever the therapeutic scheme. The dose and mode of administration were those usually used in rheumatoid arthritis $(3 \mathrm{mg} / \mathrm{kg}$ infusion of infliximab administered at weeks $0,2,6,10$, and every 8 weeks thereafter, and $25 \mathrm{mg}$ etanercept administered subcutaneously twice a week). The

Abbreviations: ASD, adult onset Still's disease; DMARD, disease modifying antirheumatic drug; MRI, magnetic resonance imagiing 
study required no minimal duration of treatment, and all patients having received at least one injection or infusion were included.

\section{Efficacy and tolerance of anti-TNF $\alpha$ therapy}

The symptoms and circumstances having led to anti-TNF $\alpha$ therapy were recorded. The response to anti-TNF $\alpha$ was defined in three categories on the basis of the opinion of the physician in charge of the patient: remission was defined as a complete resolution of all clinical and biological ASD related symptoms, except joint erosion; failure was defined as an absence of significant improvement within $1-3$ months following treatment start; and partial remission was defined as the persistence of one or several ASD related symptoms. In the latter case, the remaining symptoms were recorded. In the case of therapy discontinuation, the reason for discontinuation was recorded. All side effects, either suspected or certain, were also noted.

\section{RESULTS}

The survey identified 20 ASD patients in 12 different rheumatology or internal medicine departments. The mean age was 32.2 (19) years (median 28 years) at ASD diagnosis and 40.7 (17) years (median 34.5 years) at anti-TNF $\alpha$ therapy start (table 1). The ratio of males to females was 1 to 4 (5 men, 15 women). All patients satisfied Yamaguchi criteria for ASD. ${ }^{29}$ Any other differential diagnoses had been ruled out. In four patients, the disease began during childhood, and the patients had active disease up to the adult age. At the time of anti-TNF $\alpha$ therapy, all patients were adult. Mean disease duration at therapy start was 8.5 (6) years (median 6.5 years, range 2-21 years). In five patients, the disease was predominantly systemic (mainly fever, arthralgia, and rashes); in 15, chronic polyarthritis was the dominant feature. All patients had had several treatments (table 1), especially prednisone and methotrexate, before anti-TNF $\alpha$ therapy.

All patients had refractory active disease at the start of anti-TNF $\alpha$ therapy (table 2 ). Ten received infliximab only and five etanercept only. In five cases, patients were successively treated by both drugs: four received etanercept first, then infliximab because of lost efficacy; one received the reverse sequence after experiencing a systemic anaphylactic reaction after the third infliximab infusion. All but two patients received anti-TNF $\alpha$ in association with oral prednisone. Six patients receiving etanercept also took another DMARD (four methotrexate, one azathioprine, and one IV Ig) and 14 receiving infliximab took another DMARD ( 12 methotrexate, two azathioprine). The mean treatment duration was 11 (9) months for etanercept and 9 (7) months for infliximab.

The mean follow up was 13 months for etanercept and 14 for infliximab (median 9 and 10 months, respectively) (table 3). Anti-TNF $\alpha$ efficacy was discernable within 2-6 weeks following treatment start. Complete remission was observed in only five patients (one treated with etanercept and four with infliximab). Most patients achieved a partial remission: 16 of 25 treatments (7/10 receiving etanercept and 9/15 infliximab). One patient had a partial and dissociated response to etanercept: all symptoms but fever improved. After a few months, a global flare occurred and etanercept was discontinued. Finally, failure to respond to anti-TNF $\alpha$ therapy was noted in four patients. Both forms of the disease seemed to have similar response patterns to therapy. Partial remission was achieved in $80 \%$ of patients (4/ 5 systemic; 12/15 articular ASD).

Five patients switched etanercept and infliximab treatment: four received first etanercept then infliximab, and one had the reverse combination (fig 1). In all cases, the switch was made because the first anti-TNF $\alpha$ was ineffective; one case had concomitant skin rash, which accelerated the
Table 1 Summary of patient characteristics

\begin{tabular}{|c|c|}
\hline \multicolumn{2}{|l|}{ Characteristic } \\
\hline \multicolumn{2}{|l|}{ Age at ASD diagnosis } \\
\hline Mean (SD) (range) & $\begin{array}{l}32.2(19) \\
(11 \text { to } 72)\end{array}$ \\
\hline Median & 28 \\
\hline Childhood onset (no.) & 4 \\
\hline $\begin{array}{l}\text { Disease free interval between childhood and } \\
\text { adult symptoms }\end{array}$ & 1 \\
\hline \multicolumn{2}{|l|}{ Disease duration (years) } \\
\hline Mean (SD) (range) & $\begin{array}{l}8.5(6) \\
(2 \text { to } 21)\end{array}$ \\
\hline Median & 6.5 \\
\hline \multicolumn{2}{|l|}{ Age at anti-TNF start (years) } \\
\hline Mean (SD) (range) & $\begin{array}{r}40.7(17) \\
(18 \text { to } 74)\end{array}$ \\
\hline Median & 34.5 \\
\hline \multicolumn{2}{|l|}{ Predominant clinical expression } \\
\hline Chronic arthritis & 15 \\
\hline Systemic & 5 \\
\hline \multicolumn{2}{|l|}{ Symptoms (no.) } \\
\hline Fever & 20 \\
\hline Arthralgia & 20 \\
\hline Polyarthritis & 18 \\
\hline Sore throat/pharyngitis & 14 \\
\hline Rash & 16 \\
\hline Seritis & 4 \\
\hline Lymphadenopathy & 6 \\
\hline Increased leukocyte level & 20 \\
\hline Polymorphonuclear level $>10000 \mathrm{~mm}^{3}$ & 20 \\
\hline Abnormal liver function test result & 6 \\
\hline High serum ferritin level & 14 \\
\hline $\begin{array}{l}\text { Disseminated intravascular coagulation } \\
\text { syndrome }\end{array}$ & 5 \\
\hline \multicolumn{2}{|l|}{ Previous treatments } \\
\hline Prednisone & 20 \\
\hline Methotrexate & 20 \\
\hline Intravenous polyvalent immunoglobulin & 5 \\
\hline Sulfasalazine & 2 \\
\hline Hydroxychloroquine & 6 \\
\hline Gold salts & 2 \\
\hline D-Penicillamin & 1 \\
\hline Thalidomide & 1 \\
\hline Cyclosporine A & 5 \\
\hline Cyclophosphamide & 4 \\
\hline Azathioprine & 3 \\
\hline
\end{tabular}

discontinuation of infliximab. In all but two cases, the alternative agent produced an insufficient response, and after a mean follow up of 6 months, the second agent was discontinued. One patient had a skin rash that led to etanercept discontinuation. Another case had an accidental serious burn of the upper limbs that required infliximab discontinuation, despite a partial but significant response of ASD.

At the last follow up, the agents had been discontinued in 17/25 treatment sequences (7/10 etanercept, 10/15 infliximab; table 4), the main reason being a lack of efficacy. Side effects were responsible for discontinuation in three patients. One patient had a skin rash and blurred vision, and received a diagnosis of optic neuritis. Antinuclear antibodies were present at a titre of $1 / 80$, without any reactivity for double stranded DNA, soluble antigens, or histons, and the skin biopsy suggested an allergic origin (no lupus band on immunofluorescence analysis). Brain magnetic resonance imaging (MRI) and angio-MRI results were normal, as was visual evoked potential. With discontinuation of infliximab, all symptoms resolved within 6 months. A 74 year old woman died of cardiac failure 2 weeks after the second infliximab infusion. She had had one episode of pericarditis and arrhythmia when ASD was diagnosed 2 years before anti-TNF $\alpha$ therapy, but had had no other cardiac symptoms during the course of the disease. After the second infusion, 


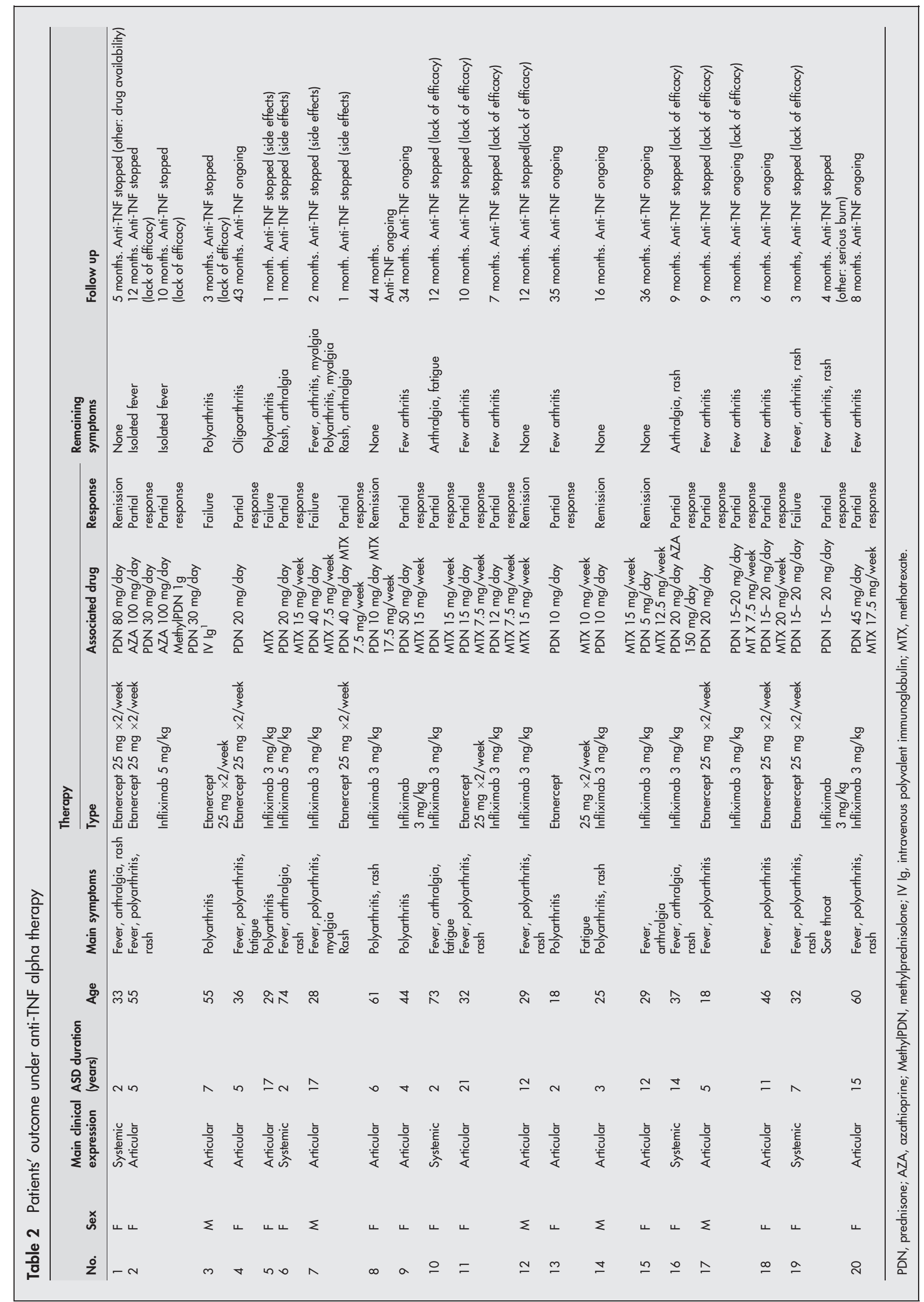


Table 3 Treatment response

\begin{tabular}{llll}
\hline & $\begin{array}{l}\text { All } \\
\text { treatments } \\
(\mathbf{n}=\mathbf{2 5})^{*}\end{array}$ & $\begin{array}{l}\text { Etanercept } \\
(\mathbf{n}=10)\end{array}$ & $\begin{array}{l}\text { Infliximab } \\
\text { (n= 15) }\end{array}$ \\
\hline $\begin{array}{l}\text { Treatment duration } \\
\text { (months) }\end{array}$ & & & \\
$\quad \begin{array}{l}\text { Mean (SD) } \\
\text { Median }\end{array}$ & $13(14)$ & $13(14)$ & $14(14)$ \\
$\begin{array}{l}\text { Range } \\
\text { Response to therapy }\end{array}$ & 9 & 9 & 10 \\
$\quad \begin{array}{l}\text { Complete remission } \\
\text { Partial response }\end{array}$ & 5 & 1 to 43 & 1 to 44 \\
$\quad$ Failure & 16 & 1 & 4 \\
\hline
\end{tabular}

${ }^{*} \mathrm{~A}$ total of 25 treatments in 20 patients were analysable. 10 patients received etanercept, 15 infliximab, and 5 both drugs.

she developed high fever $\left(39^{\circ} \mathrm{C}\right)$ and features of refractory cardiac failure, the exact origin remaining unknown. The third patient discontinued both infliximab and etanercept because of an allergic skin reaction.

Mild side effects were observed in seven patients (table 5). Three patients had skin rashes, which responded to antihistamine treatments. Serious side effects occurred in two patients. One had recurrent bronchitis and an episode of pneumonia requiring antibiotics. However, it was possible to maintain therapy with only minor changes in the infliximab infusion periodicity. Another case had a spontaneous thigh abscess. Antibiotics and etanercept discontinuation resolved the abscess without need for surgical intervention; anti-TNF $\alpha$ therapy was reintroduced within 2 months, without further infection.

\section{DISCUSSION}

Compared with previously published papers, the present series brings additional relevant data on the efficacy of anti$\mathrm{TNF} \alpha$ agents in refractory ASD, thanks to the number of

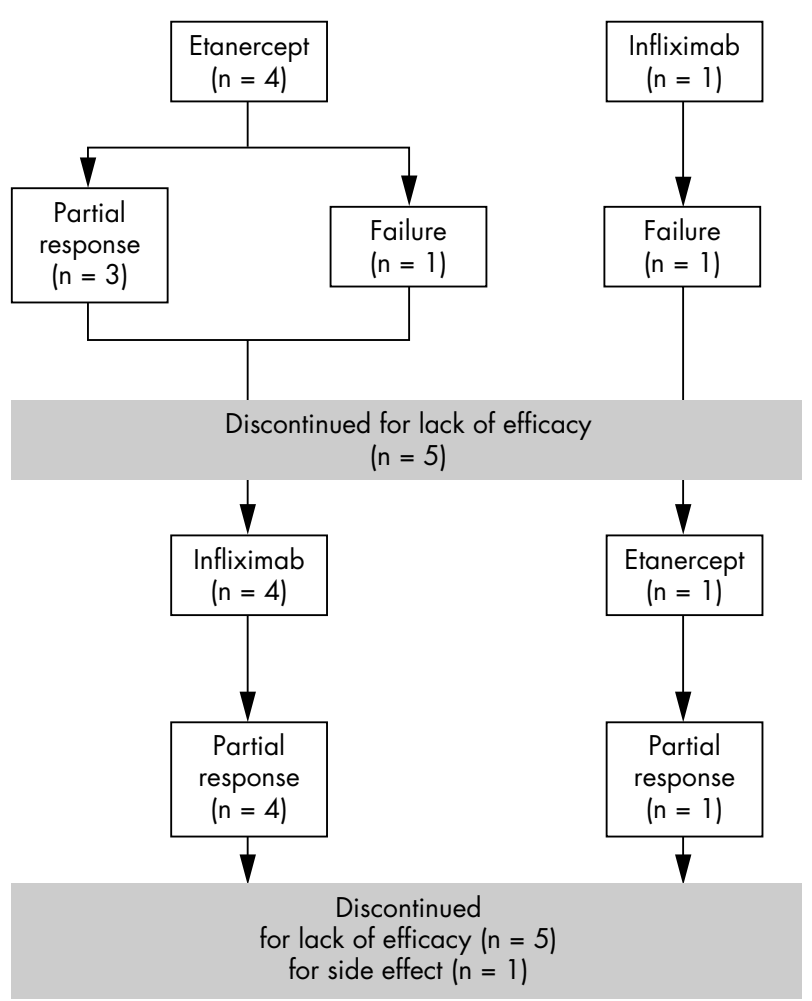

Figure 1 Breakdown of the five patients with anti-TNF $\alpha$ switches.
Table 4 Anti-TNF $\alpha$ discontinuation

\begin{tabular}{llll}
\hline & $\begin{array}{l}\text { Both } \\
\text { treatments } \\
(\mathbf{n = 2 5 )}\end{array}$ & $\begin{array}{l}\text { Etanercept } \\
(\mathbf{n = 1 0 )}\end{array}$ & $\begin{array}{l}\text { Infliximab } \\
(\mathbf{n}=\mathbf{1 5})\end{array}$ \\
\hline Discontinuation & 17 & 7 & 10 \\
Lack of efficacy & 11 & 5 & 6 \\
Side effect & 4 & 1 & 3 \\
Other & 2 & 1 & 1 \\
\hline
\end{tabular}

patients, the presence of both systemic or articular forms of the disease, the use of either infliximab, etanercept, or both, and a rather long follow-up ( 13 months; up to 44 months for some patients). The retrospective design of our study is a limitation, but prospective randomised control trials are difficult to conduct for ASD. This limitation is shared by most of the studies published so far, ${ }^{25-27}$ which included only a few patients, six at maximum. Only one series, of 12 cases, used a prospective, open label design and reported the efficacy of etanercept in patients with a polyarticular form of ASD. ${ }^{28}$

As our study was retrospective and collected data from all over France, we tried to homogenise the information by defining three clinical responses based on physicians' opinions. With use of this classification, we found that when anti-TNF $\alpha$ agents were efficacious, clinical improvement occurred rapidly, within the first month of treatment. Complete remission was possible under both agents but was rare, only $5 / 20$ cases, which is consistent with data from the literature. ${ }^{26}{ }^{28}$ Partial response was observed in most patients (16/25 cases) in our series as well as in those of the literature. Only one patient experienced a remission of joint and skin symptoms without any substantial change in fever spikes. Such a dissociation had already been mentioned in ASD with use of other DMARDs ${ }^{16}$ and etanercept. ${ }^{28}$ The patients with a systemic form of ASD seemed to respond the same as the patients with an articular form of the disease.

The present series offers information about the efficacy of switching from one anti-TNF $\alpha$ to the other. In opposition to what has already been suggested for rheumatoid arthritis, ${ }^{30}$ such a switch did not seem to be efficacious in ASD. Two patients in whom therapy with one anti-TNF $\alpha$ failed showed partial response to the other; however, the response was transient and led to rapid discontinuation of the second agent. For the three other cases, a partial and transient response was observed with use of both drugs. The pathogenic basis of such occurrences is unknown. In general, the safety of anti-TNF $\alpha$ therapy was in accordance with what has been described for rheumatoid arthritis, psoriasitic arthritis, ankylosing spondylitis, or inflammatory enterocolitis. ${ }^{31-33}$ We did not observe any cases of tuberculosis, which is probably explained by the large diffusion of warnings from pharmaceutical firms or governmental agencies at the time of

\begin{tabular}{llll}
$\begin{array}{l}\text { Table } 5 \\
\text { therapy }\end{array}$ & Side effects reported under anti-TNF alpha \\
\hline & $\begin{array}{l}\text { Both } \\
\text { treatments } \\
(\mathbf{n}=25)\end{array}$ & $\begin{array}{l}\text { Etanercept } \\
(\mathbf{n}=10)\end{array}$ & $\begin{array}{l}\text { Infliximab } \\
(\mathbf{n}=15)\end{array}$ \\
\hline $\begin{array}{l}\text { Rash } \\
\text { Infections }\end{array}$ & 5 & 3 & 2 \\
Other & 2 & $\begin{array}{l}1 \text { (recurrent } \\
\text { bronchitis) } \\
2 \text { (1 lupus rash + } \\
\text { optic neuritis; } \\
\text { cardiac failure) }\end{array}$ & $\begin{array}{l}1 \text { (thigh } \\
\text { abscess) }\end{array}$ \\
\hline
\end{tabular}


the study. Other infectious side effects, noted in the literature, ${ }^{27}$ were found in our series; no life threatening infection was recorded. Skin rashes were observed in our patients but were distinguishable from ASD specific skin lesions: they were pruritic urticarian lesions occurring soon after anti-TNF $\alpha$ injection or infusion, and had no vesperal timing and relation to fever spikes. The most serious side effect was an anti-TNF $\alpha$ induced autoimmune reaction in one patient, who had a skin rash and optic neuritis. Such events have been reported after anti-TNF $\alpha$ therapy in patients with other inflammatory conditions. ${ }^{34-36}$ In general, therapy discontinuation resolved the symptoms.

In conclusion, anti-TNF $\alpha$ agents may be useful in the treatment of refractory ASD. However, this therapy does not seem to be as efficacious in ASD as in rheumatoid arthritis or spondylarthropathies.

\section{ACKNOWLEDGEMENTS}

The authors want to acknowledge the physicians who provided the 20 observations: Professor M Alcalay, Rheumatology, La Mileterie Hospital, Poitiers; Professor Z Amoura, Internal Medicine, PitieSalpetriere University Hospital, Paris; Dr S Berthier, Internal Medicine, Le Bocage Hospital, Dijon; Dr F Bonnet, Internal Medicine, University Hospital, Bordeaux; Dr C Dumoulin, Rheumatology, Pellegrin Hospital, Bordeaux; Professor P Gaudin, Rheumatology, A Michallon Hospital, Grenoble; Dr J-E Gottenberg, Rheumatology, Cochin Hospital, Paris; Dr L Lequen, Rheumatology, General Hospital, Pau; Professor P Mercié, Internal Medicine, SaintAndre Hospital, Bordeaux; Dr B Moura, Rheumatology, Ambroise Paré Hospital, Boulogne; Dr X Puéchal, General Hospital, Le Mans; Professor A Saraux, Rheumatology, La Cavale Blanche Hospital, Brest; Dr S Schrambach, Haute-Pierre Hospital, Strasbourg; Dr J-F Viallard, Internal Medicine, Haut-Leveque Hospital, Bordeaux.

\section{Authors' affiliations}

B Fautrel, Department of Rheumatology, Pitié-Salpêtrière Hospital, APHP, Paris, France

J Sibilia, Department of Rheumatology, Hautepierre University Hospital, Strasbourg, France

X Mariette, Department of Rheumatology, Bicêtre Hospital, AP-HP, Le Kremlin Bicêtre, France

B Combe, Federation of Rheumatology, Lapeyronie University Hospital, Montpellier, France

The study was funded by the The Club Rhumatismes and Inflammation (CRI) section of the French Society of Rheumatology.

\section{REFERENCES}

1 Bywaters EG. Still's disease in the adult. Ann Rheum Dis 1971;30:121-33.

2 Magadur-Joly G, Billaud E, Barrier JH, Pennec YL, Masson C, Renou P, et al. Epidemiology of adult Still's disease: estimate of the incidence by a retrospective study in west France. Ann Rheum Dis 1995;54:587-90.

3 Wakai K, Ohta A, Tamakoshi A, Ohno Y, Kawamura T, Aoki R, et al. Estimated prevalence and incidence of adult Still's disease: findings by a nationwide epidemiological survey in Japan. J Epidemiol 1997;7:221-5.

4 Reginato AJ, Schumacher HR Jr, Baker DG, CR OC, Ferreiros J.. Adult onset Still's disease: experience in 23 patients and literature review with emphasis on organ failure. Semin Arthritis Rheum 1987;17:39-57.

5 Ohta A, Yamaguchi M, Tsunematsu T, Kasukawa R, Mizushima H, Kashiwagi $\mathrm{H}$, et al. Adult Still's disease: a multicenter survey of Japanese patients. J Rheumatol 1990;17:1058-63.

6 Pouchot J, Sampalis JS, Beaudet F, Carette S, Decary F, SalusinskySternbach $M$, et al. Adult Still's disease: manifestations, disease course, and outcome in 62 patients. Medicine (Baltimore) 1991;70:118-36.

7 Masson C, Le Loet X, Liote F, Renou P, Dubost JJ, Boissier MC, et al. Adult Still's disease: part I. Manifestations and complications in sixty-five cases in France. Rev Rhum Engl Ed 1995;62:748-57.
8 Masson C, Le Loet X, Liote F, Renou P, Dubost JJ, Boissier MC, et al. Adult Still's disease. Part II. Management, outcome, and prognostic factors. Rev Rhum Engl Ed 1995;62:758-65.

9 Ohta A, Yamaguchi M, Kaneoka H, Nagayoshi T, Hiida M. Adult Still's disease: review of 228 cases from the literature. J Rheumatol 1987; 14:1139-46.

10 Wouters JM, van de Putte LB. Adult-onset Still's disease; clinical and laboratory features, treatment and progress of 45 cases. Q J Med 1986;61:1055-65.

11 Cush JJ, Medsger TA Jr, Christy WC, Herbert DC, Cooperstein LA. Adult-onset Still's disease. Clinical course and outcome. Arthritis Rheum 1987;30:186-94.

12 Khraishi M, Fam AG. Treatment of fulminant adult Still's disease with intravenous pulse methylprednisolone therapy. J Rheumatol 1991;18:1088-90

13 Bisagni-Faure A, Job-Deslandre C, Menkes CJ. Intravenous methylprednisolone pulse therapy in Still's disease. J Rheumatol 1992;19:1487-8.

14 Marchesoni A, Ceravolo GP, Battafarano N, Rossetti A, Tosi S, Fantini F. Cyclosporin $A$ in the treatment of adult onset Still's disease. J Rheumatol 1997;24:1582-7.

15 Shojania K, Chalmers A, Rangno K. Cyclosporin A in the treatment of adult Still's disease. J Rheumatol 1995;22:1391-2.

16 Kraus A, Alarcon-Segovia D. Fever in adult onset Still's disease. Response to methotrexate. J Rheumatol 1991;18:918-20.

17 Aydintug AO, D DC, Cervera R, Khamashta MA, Hughes GR. Low dose methotrexate treatment in adult Still's disease. J Rheumatol 1992;19:431-5.

18 Fujii T, Akizuki M, Kameda H, Matsumura M, Hirakata M, Yoshida T, et al. Methotrexate treatment in patients with adult onset Still's diseaseretrospective study of 13 Japanese cases. Ann Rheum Dis 1997;56:144-8.

19 Fautrel B, Borget C, Rozenberg S, Meyer O, Le Loet X, Masson C, et al. Corticosteroid sparing effect of low dose methotrexate treatment in adult Still's disease. J Rheumatol 1999;26:373-8.

20 Permal S, Wechsler B, Cabane J, Perrot S, Blum L, Imbert JC. Treatment of Still disease in adults with intravenous immunoglobulins. Rev Med Interne 1995; 16:250-4.

21 Vignes S, Wechsler B, Amoura Z, Papo T, Frances C, Huong DL, et al. Intravenous immunoglobulin in adult Still's disease refractory to non-steroidal anti-inflammatory drugs. Clin Exp Rheumatol 1998;16:295-8.

22 Vignes S, Le Moel G, Fautrel B, Wechsler B, Godeau P, Piette JC. Percentage of glycosylated serum ferritin remains low throughout the course of adult onset Still's disease. Ann Rheum Dis 2000;59:347-50.

23 Furst DE, Breedveld FC, Kalden JR, Smolen JS, Burmester GR, Dougados M, et al. Updated consensus statement on biological agents for the treatment of rheumatoid arthritis and other immune mediated inflammatory diseases. Ann Rheum Dis 2003;62:2-9.

24 Blumenauer B, Judd M, Wells G, Burls A, Cranney A, Hochberg M, et al. Infliximab for the treatment of rheumatoid arthritis. Cochrane Database Syst Rev, 2002;CD003785.

25 Cavagna L, Caporali R, Epis O, Bobbio-Pallavicini F, Montecucco C. Infliximab in the treatment of adult Still's disease refractory to conventional therapy. Clin Exp Rheumatol 2001;19:329-32.

26 Kraetsch HG, Antoni C, Kalden JR, Manger B. Successful treatment of a small cohort of patients with adult onset of Still's disease with infliximab: first experiences. Ann Rheum Dis 2001;60:55-7.

27 Tamesis ER, Reginato AM, Hubscher O, Reginato AJ. Etanercept in recalcitrant adult onset Still's disease. Arthritis Rheum 2000;43:S229.

28 Husni ME, Maier AL, Mease PJ, Overman SS, Fraser P, Gravallese EM, et al. Etanercept in the treatment of adult patients with Still's disease. Arthritis Rheum 2002;46:1171-6.

29 Yamaguchi M, Ohta A, Tsunematsu T, Kasukawa R, Mizushima Y, Kashiwagi $\mathrm{H}$, et al. Preliminary criteria for classification of adult Still's disease. J Rheumatol 1992;19:424-30.

30 Buch MH, Bingham SJ, Bejarano V, White J, Emery P. Do patients with rheumatoid arthritis demonstrate an improvement on etanercept following an inadequate response to infliximab. Arthritis Rheum 2003;48:S325.

31 Antoni C, Braun J. Side effects of anti-TNF therapy: current knowledge. Clin Exp Rheumatol 2002;20:S152-7.

32 Criscione LG, St Clair EW. Tumor necrosis factor-alpha antagonists for the treatment of rheumatic diseases. Curr Opin Rheumatol 2002;14:204-11.

33 Fleischmann R, lqbal I, Nandeshwar P, Quiceno A. Safety and efficacy of disease-modifying anti-rheumatic agents: focus on the benefits and risks of etanercept. Drug Saf 2002;25: 173-97.

34 Foroozan R, Buono LM, Sergott RC, Savino PJ. Retrobulbar optic neuritis associated with infliximab. Arch Ophthalmol 2002;120:985-7.

35 Debandt M, Vittecoq O, Descamps V, Le Loet X, Meyer O. Anti-TNF-alphainduced systemic lupus syndrome. Clin Rheumatol 2003;22:56-61.

36 Shakoor N, Michalska M, Harris CA, Block JA. Drug-induced systemic lupus erythematosus associated with etanercept therapy. Lancet 2002;359:579-80. 